\title{
Topography and Volcanology of the Huangtsuishan Volcano Subgroup, Northern Taiwan
}

\author{
Yu-Ming Lai ${ }^{1}$, Yeong-Jong Lin ${ }^{1}$, Sheng-Rong Song ${ }^{1, *}$, Yu-Wei Tsai ${ }^{2,3}$, \\ $\mathrm{Yu}-\mathrm{Chung} \mathrm{Hsieh}^{4}$, and Wei $\mathrm{Lo}^{3}$ \\ ${ }^{1}$ Department of Geosciences, National Taiwan University, Taipei, Taiwan, ROC \\ ${ }^{2}$ Department of Geology, Chinese Culture University, Taipei, Taiwan, ROC \\ ${ }^{3}$ Institute of Mineral Resources Engineering, National Taipei University of Technology, Taipei, Taiwan, ROC \\ ${ }^{4}$ Central Geological Survey, Ministry of Economic Affairs, Taipei, Taiwan, ROC
}

Received 26 February 2009, accepted 22 February 2010

\begin{abstract}
Combining the shaded relief topography model and the slope map from the Digital Terrain Model (DTM) images, topographical map, field occurrences and petrography, the volcanic sequences of the Huangtsuishan Volcano Subgroup (HVS) can be constructed. Two types of volcanic centers can be identified in this area. One is the Tachienhou volcanic dome, which may be located in the center of an older caldera. The other is the Huangtsui composite volcano, which is composed of interbedding lava flows and pyroclastic deposits with a volcanic crater named the Huangtsui pond at the summit. Eight lava plateaus radiated from Mts. Huangtsui and Tachienhou to the north and the east can be distinguished based on the DTM images. The volcanic deposits are comprised of four lithofacies, the lava flows, pyroclastic breccias, tuffs and lahars on the base of field occurrences. At least thirteen layers of lava flow, named the H1 to H13 can be recognized in the HVS and can be reconstructed and categorized into four stages. An old and large volcano erupted lava flows to form the products of stages one and two, then collapsed to form a caldera with a dome for the third stage. The latest stage of lava flow was poured out from the Huangtsui volcano, which formed a crater at the summit.
\end{abstract}

Key words: Tatun Volcano Group, Huangtsuishan Volcano Subgroup, DTM images, Lava flow, Lava plateau

Citation: Lai, Y. M., Y. J. Lin, S. R. Song, Y. W. Tsai, Y. C. Hsieh, and W. Lo, 2010: Topography and volcanology of the Huangtsuishan Volcano Subgroup, northern Taiwan. Terr. Atmos. Ocean. Sci., 21, 599-609, doi: 10.3319/TAO.2010.02.22.04(TH)

\section{INTRODUCTION}

Digital Earth is a new and popular subject to study the topography, environment, praxiology, etc. Several techniques are suitable surveying methods for geographic information, including GPS kinematic methodology, digital aerial and terrestrial photogrammetry, airborne and terrestrial laser scanning, etc. (Beutler et al. 1995; Kraus 1998; Csatho et al. 2005). The Digital Terrain Model (DTM) and Digital Surface Models (DSM) are two kinds of Digital Elevation Model (DEM) which were suggested by Miller and Leflamme (1958). Burrough and McDonell (1998) defined the DEM as a space array, which indicated the site $(\mathrm{x}, \mathrm{y})$ and the altitude (z) of land surface. The DTM is usually utilized for aerial/ surface survey or digital terrain map to obtain the altitude

\footnotetext{
* Corresponding author

E-mail: srsong@ntu.edu.tw
}

data of topography and presentation three major ways: digital contour, triangulated irregular network (TIN) and regular grid. The DTM is an application of topography, geology, hydrology and engineering, and different scales need different degree of resolutions (Wilson and Gallant 2000).

Taiwan is a member of the Ryukyu-Taiwan-Philippine island arc chains of the western Pacific Ocean, and is an active mountain belt created by the oblique collision between the northern Luzon arc and the Asian continent (Ho 1986; Teng 1990). The Northern Taiwan Volcanic Zone (NTVZ) is considered to be the young volcanism resulted from postcollisional lithospheric extension in the northern Taiwan mountain belt (Wang et al. 1999) (Fig. 1a). However, some researchers suggested that magmatism in northern Taiwan might be related with northward subduction of the Philippine Sea plate into the Eurasian plate (Wu 1978; Tsai et al. 1981; Suppe 1984). 


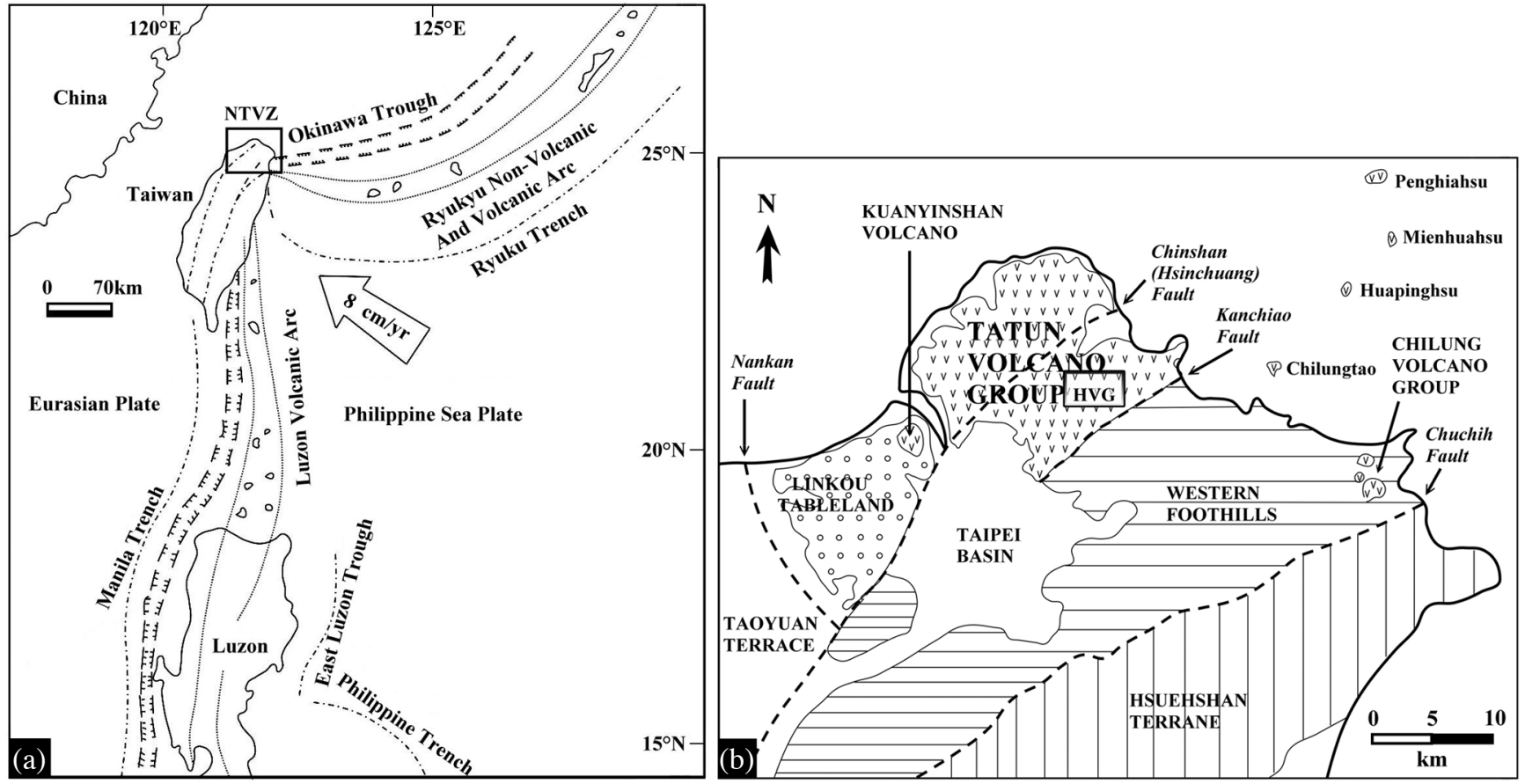

Fig. 1. Tectonic map of Taiwan and geological map of the study area. (a) NTVZ is young volcanism resulting from post-collisional lithospheric extension in the northern Taiwan mountain belt (square marked); (b) Geological map of the TVG.; the marked square is the area of HVG. (Modified from Ho 1986).

The Tatun Volcano Group (TVG) is one of the most extensive areas of NTVZ (Fig. 1b) includes volcanic domes, lava flows, pyroclastics and epiclastics (Chen and Wu 1971; Song et al. 2000a) and lies between two major thrust faults, the Chinshan (Hsinchuang) Fault and the Kanchiao Fault. About 20 volcanoes can be categorized into five volcano subgroups: the Chutzeshan, Tatunshan, Chihsingshan, Huangtsuishan, and Nantzeshan-Tinghuohsiushan. The TVG is predominantly composed of andesitic rocks, the volcanic landforms preserved very well, and its principal lithofacies are lava flows (Chen and Wu 1971; Song et al. 2000a). According to radiometric dating data, the volcanic activity of the TVG can be divided into two periods (Juang and Chen 1989; Wang and Chen 1990; Tsao 1994; Lee 1996; Song et al. 2000a). It began to erupt ca. $2.8 \sim 2.5 \mathrm{Ma}$, then ceased about one million years and revived during $1.5 \sim 0.2 \mathrm{Ma}$ caused by extensional collapse (Wang et al. 1999; Song et al. 2000a). The TVG was considered dormant previously. However, Chen and Lin (2002) and Chen and Lin (2007) reported some young eruption products in the Taipei Basin with ages less than $20 \mathrm{ka}$. In addition, helium isotopic results (Yang et al. 1999; Yang 2000; Lee et al. 2008) and volcanoseismic signals (Lin et al. 2005a, b) showed that it probably still has some interaction between magmatic fluids and solid rocks underneath this area. The TVG, thus, may be still an active volcano (Song et al. 2000b).

Studying active volcanism helps us to understand and avoid or mitigate volcanic hazards, including lava flows, pyroclastic flows and lahars. The Huangtsuishan Volcano Subgroup (HVS) has preserved the most complete volcanic landforms and may be the youngest volcano in the TVG. In this study, we used the DTM images from the TVG to identify the volcanic cones, craters, caldera, domes and lava plateaus of the HVS, and identify and separate each sequence of lava flows. Then, a field survey was conducted to make sure of rock types and distributions of each lava effusion. Combined with topography and lithofacies, we could reveal the volcanic evolution of the HVS. Moreover, it also provides the basic information of past volcanic characteristics for further mitigation.

\section{METHODS AND ANALYSIS}

The DTM in Taiwan were made from aerial photography by the Aerial Survey Office, Forestry Bureau since $1980 \mathrm{~s}$. Most of these $40 \mathrm{~m} \times 40 \mathrm{~m}$ DTM data could be purchased except confidential areas of military purpose. Recently, the Airborne Light Detection and Ranging (LiDAR) survey was completed by the Central Geological Survey (CGS), Ministry of Economic Affairs (MOEA) in north Taiwan and can provide DTM images up to a resolution of $2 \mathrm{~m} \times 2 \mathrm{~m}$.

Different resolutions, i.e., the $40 \mathrm{~m} \times 40 \mathrm{~m}, 10 \mathrm{~m} \times$ $10 \mathrm{~m}$, and $2 \mathrm{~m} \times 2 \mathrm{~m}$ of DTMs from the HVS were used for this study. They were used to gather topographic data, slope analyses and shaded relief map for comparison with 
results derived from 1/5000 topographic charts and field observations. The software used in this study includes the ArcGIS 8.1 and the Photoimpact 12. A field survey was also conducted for parallel checking the volcanic landforms and sequences identified from DTM images and sampling. Fifty-one specimens were collected from the HVS area to make thin sections for petrographic study.

\section{RESULTS}

\subsection{The Digital Topography Model, DTM}

\subsubsection{Shaded Relief Topography Model}

Software of ArcGIS 8.1 was used to model the sun's azimuth and altitude for three different scale resolutions of the DTM, which are $40 \mathrm{~m} \times 40 \mathrm{~m}, 10 \mathrm{~m} \times 10 \mathrm{~m}$, and $2 \mathrm{~m}$ $\times 2 \mathrm{~m}$, respectively (Figs. $2 \mathrm{a}-\mathrm{c}$ ). The $40 \mathrm{~m} \times 40 \mathrm{~m}$ DTM image can only show the mountains' outline. The large lava plateaus, Ta and Erh are identifiable under this resolution (Fig. 2a). Although the center of Huangtsui volcano is obvious, this resolution of DTM image is insufficient for our topographic survey. Under the resolution of $10 \mathrm{~m} \times 10 \mathrm{~m}$, the mountain's outlines and the landforms are more obvious (Fig. 2b). Figure 3 is the topographic model of the contour lines with $50 \mathrm{~m}$ interval in the HVS area, which Mts. Huangtsui and Tachienhou can be recognized as the main volcanic centers. The U-shape of crater with a northern breach is preserved very well on the summit of Mt. Huangtsui.

On purpose is to recognize the detailed volcanic landforms, structures and sequences in the HVS area, using the resolution of $2 \mathrm{~m} \times 2 \mathrm{~m}$ DTM image from LiDAR (Fig. 2c). Lava flows and lava lobes with orientations from the volcanic centre toward the north and the east to form lava pla-

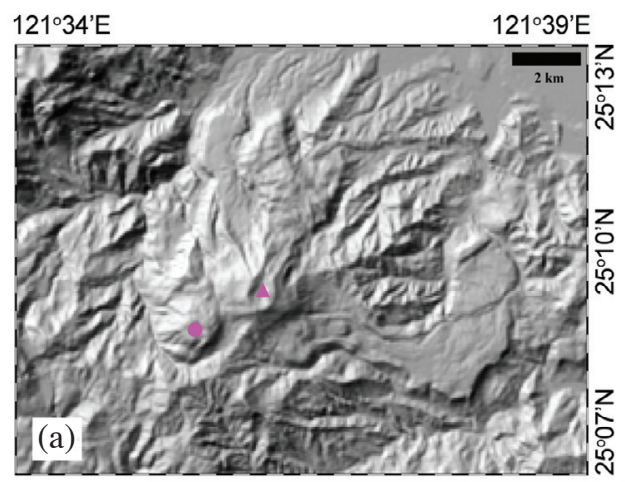

$121^{\circ} 34^{\prime} \mathrm{E}$

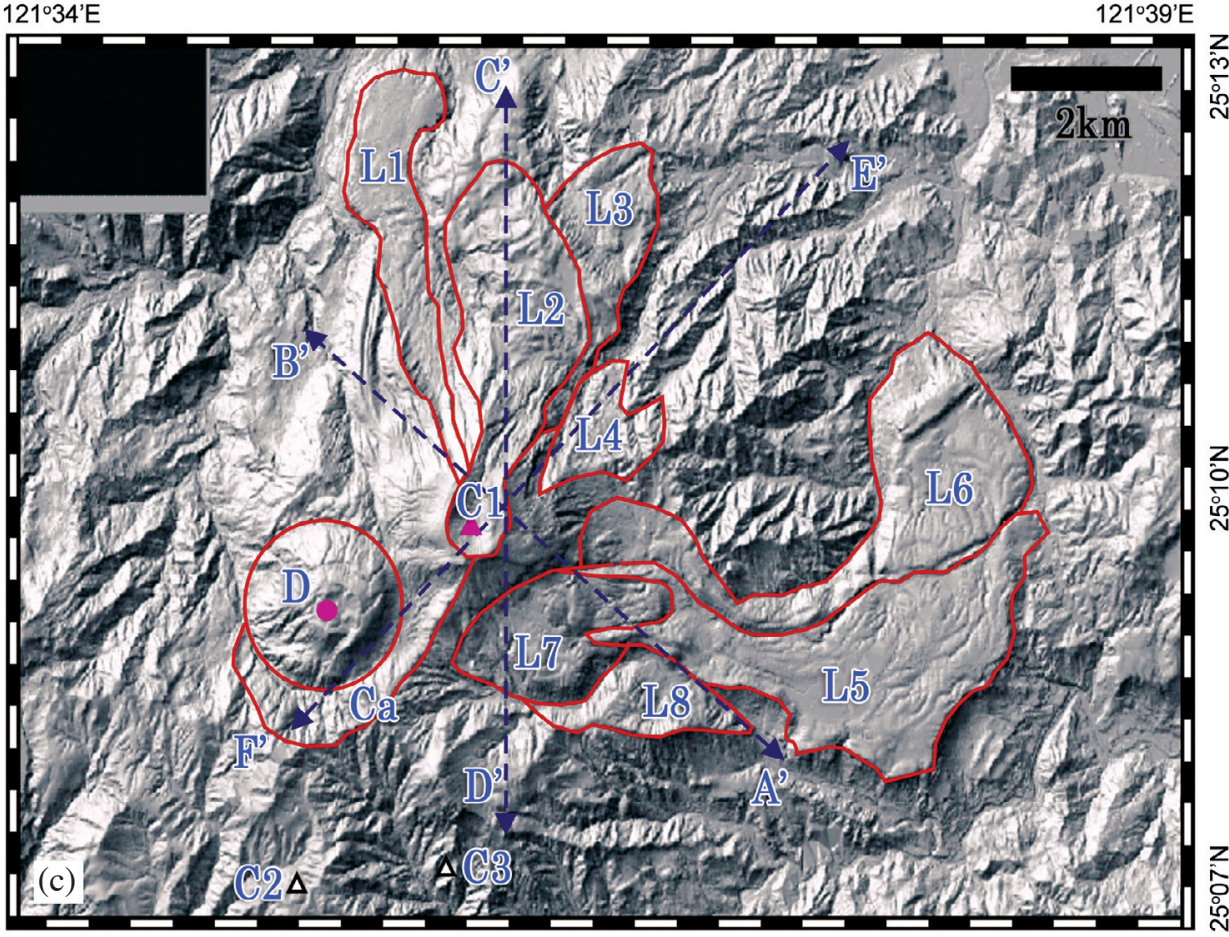

Fig. 2. Different scale resolutions of the DTM images in the HVG. (a) $40 \mathrm{~m} \times 40 \mathrm{~m}$; (b) $10 \mathrm{~m} \times 10 \mathrm{~m}$; (c) $2 \mathrm{~m} \times 2 \mathrm{~m}$. D: Tachienhou lava dome; C1 - C3: craters of Huangtsui, Singlin and Tachien volcano; Ca: old caldera; L: lava plateaus of L1: Szuhuang, L2: Hsiufeng, L3: Kengtze, L4: Huanshan, L5: Ta, L6: Erh, L7: Luku, L8: Fushih. A: Mt. Huangtsui, @: Mt. Tachienhou, $\triangle$ : Mt. Singlin and Tachien. 


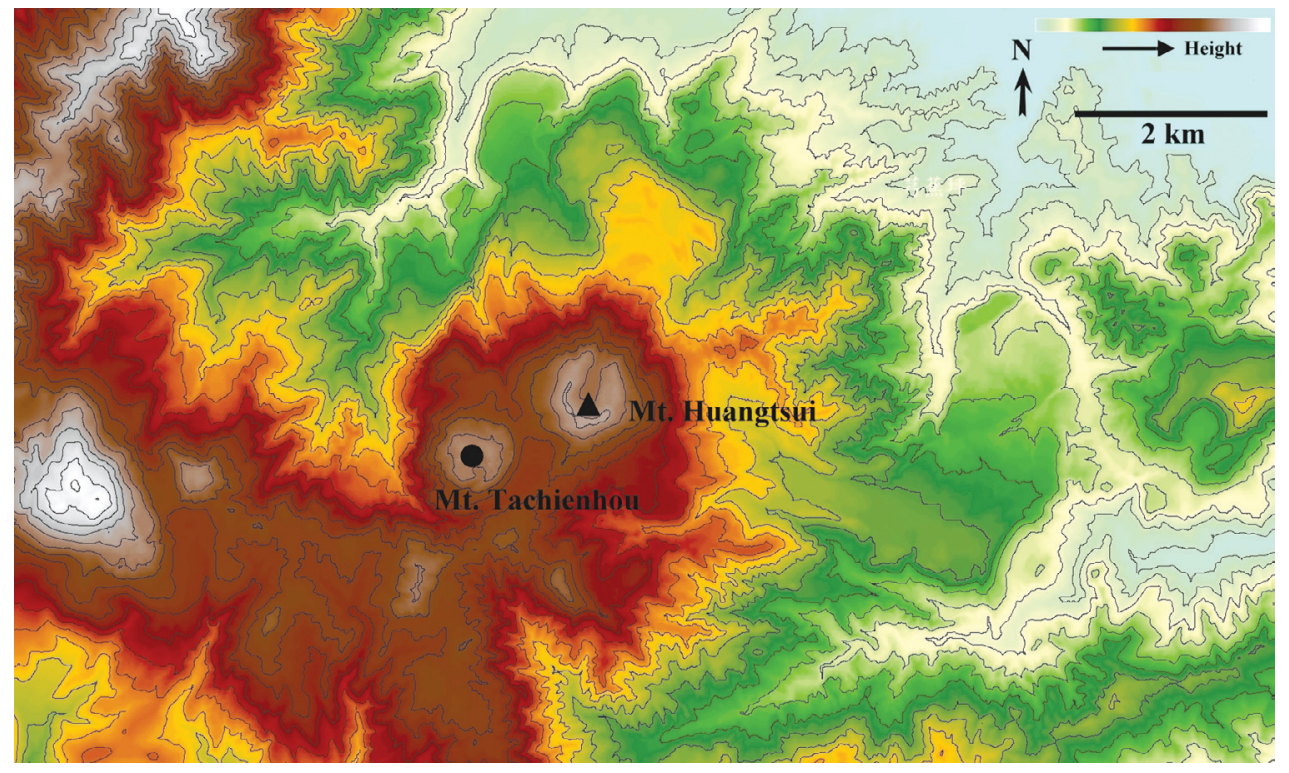

Fig. 3. The topographic contour lines with $50 \mathrm{~m}$ interval in the HVS area, the U-shape of crater with a northern breach is on the summit of Mt. Huangtsui. The symbols are the same as in Fig. 2.

teaus could be revealed. The boundary between different lava flows and the structures at the contact zone can be distinguished by the law of crosscutting relationships, which were also used to judge their eruption sequences.

According to the high-resolution LiDAR shaded relief topography model, several volcanic landforms can be identified from the HVS area, including volcanic cones, craters, calderas, domes and lava plateaus (Fig. 2c). There are two volcanic centers in this area, Mts. Huangtsui and Tachienhou. Mt. Huangtsui is a composite volcano composed of interbedding lava flows and pyroclastic deposits exhibiting a steep top and gentle bottom. The best preserved volcanic crater in the TVG is the Huangtsui pond located at the summit of Mt. Huangtsui. The Tachienhou volcanic dome is located at the left side of the Huangtsui crater and is considered to be also located in the center of a large caldera (Fig. 2c). Two other craters could also be found at Mts. Singlin and Tachien (Fig. 2c). Two groups of lava plateaus radiated from Mts. Huangtsui and Tachienhou to the north and the east, respectively. The former includes the Szuhuang, Hsiufeng, Kengtze and Huanshan plateaus, while the later is composed of the Ta, Erh, Luku and Fushih plateaus (Fig. 2c). The lobated, banded and ringed lava flows can also be identified in the northern part of this volcano subgroup that formed different lava plateaus according to eruption time and the distances away from the volcanic center (Fig. 2c).

To summarize the volcanic landforms and structures from the DTM images, the HVS is the most complicated subgroup in the TVG. It includes the volcanoes of Huangtsui, Tachienhou, Singlin and Tachien. Several massive and thick lava flows from Huantsui and Tachienhou volcanoes formed eight plateaus, namely, plateaus Szuhuang (L1), Hsiufeng (L2), Kengtze (L3), Huanshan (L4), Ta (L5), Erh (L6), Luku (L7), and Fushih (L8)(Fig. 2c).

\subsubsection{The Slope Map}

The shape or slope of volcanic or debris cones are closely relative to their magma characteristics, especially for magma viscosity. The slope of debris cones is always less than 30 degrees, while a lava cone with higher viscosity probably has a steeper slope (Decker and Decker 1981). Meanwhile, margins of lava plateau and boundaries of different lava flow can be significantly discriminated by slope changes. The slope map, therefore, transformed from the DTM has been drawn and shown different degrees of the slope with a series of colors (Fig. 4).

Volcanic cones in the TVG are sloped higher than 30 degrees (Chen et al. 2003) which indicates the nature of higher viscous magma in this volcano group. It is not the case in the HVS area wherein the slopes of volcanoes are between 20 to 30 degrees. The Tachienhou lava dome is an exception because of its convex and steeper slope (Fig. 4).

Lava flows with higher viscosity formed a steep slope in front of them, especially andesitic lava flows (Cas and Wright 1987). In light of the forgoing premise, at least eight lava plateaus can be recognized easily in the HVS (Figs. 2c and 4). All of them are characterized by a slope of less than 5 degrees on the surface of the plateau and 30 to 50 degrees in the front or margins of lava flow. There are several pressure ridges on the surface of lava plateaus which are displayed the deformed process by movements of the underflowing lava (Cas and Wright 1987). 


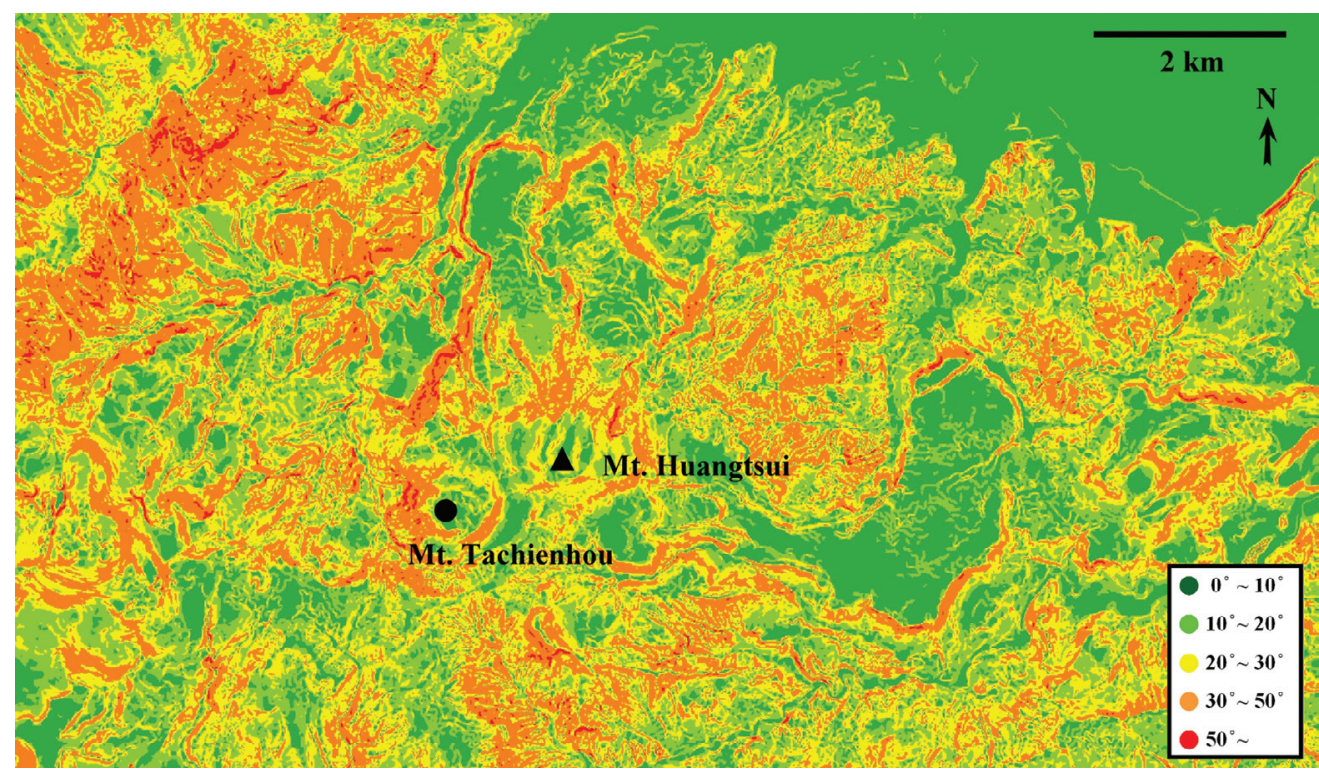

Fig. 4. The slope map of the HVG, different colors show different degrees of the slope. Dark green: less than 10 degrees; light green: degrees 10 to 20; yellow: degrees 20 to 30; orange: degrees 30 to 50; red: greater than 50 degrees. The symbols are the same as in Fig. 2.

Different forming stages of lava plateaus can also be identified based on the slope map. In general, lava plateaus with a more rugged surface may be formed earlier due to more erosion. This characteristic is another key to distinguish the sequences of a lava plateau. Accordingly, the lava plateaus of Szuhuang, Hsiufeng, and Kengtze are believed to have been formed earlier than the Ta, Erh, and Luku (Fig. 4).

\subsubsection{The Features of the Volcanic Landforms}

The distances and altitudes of the volcanic landforms away from the volcanic centers are helpful in tracing the range of lava plateaus. Treating Mt. Huangtsui as the center, three cross sections cut through it, Fig. 2c. Section A' - B' with the orientation from the southeast to the northwest is a lava plateau 400 meters high. The Fushih plateau is marked at the A' side (Fig. 5a). Section C' - D' across from the north to the south is comprised of the Hsiufeng plateau is located at the north and the Luku plateau is located at the south of Mt. Huangtsui, respectively (Fig. 5b). Perpendicular to Section A' - B', Section E' - F' shows the lava plateau of Huanshan and the Tachienhou volcanic dome (Fig. 5c).

\subsection{Field Occurrences}

We paid more attention to the occurrence and structure of volcanic rocks and the contact and sequences of different lava flows in the field work of this study to confirm the topographic results from the DTM and to depict detailed lava flow sequences in the HVS area.

\subsubsection{Volcanic Deposits}

On the basis of field occurrences, the volcanic deposits can be divided into four lithofacies. They are the lava flows, pyroclastic breccias, tuffs and lahars. The HVS is predominantly composed of andesitic lava flows with high viscosity which formed 8 lava plateaus with steeper margin and flat surface around the main volcanic edifices (Fig. 2c). The altitudes are between 300 to 650 meters high and show different eroding conditions preserved on their geomorphology and surface features which provided as evidence for identifying the sequence of lava. On the basis of DTM images, field observations, petrography of the mafic phenocrysts contents and geochemistry of host rocks, lava flows of the HVS can be distinguished into thirteen flow bodies, named as the H1 to H13 (Table 1), which interbedded with pyroclastic or volcaniclastic rocks.

Pyroclastic breccia is predominantly composed of angular to subangular lapilli and blocks with fine crystals and lithic as matrix. They are mainly distributed in the lower land and around the fringe of the HVS and partly interlayered with the lava flows. The lapilli and blocks are monolithologic andesite rich in white plagioclase phenocrysts with radiated cooling fractures. It suggests that they are formed by block and ash flows or hot avalanche deposits which originated by collapse of the dome or the volcanic edifice, respectively (Cas and Wright 1987).

Tuff is the product of pyroclastic fall in which fine airborne volcanic materials fell as deposits on the surface. It is rare, thin and clast-supported occurrence and only found near Chingteingang of the HVS. This characteristic infers that the HVS had a tendency to weak explosions. 

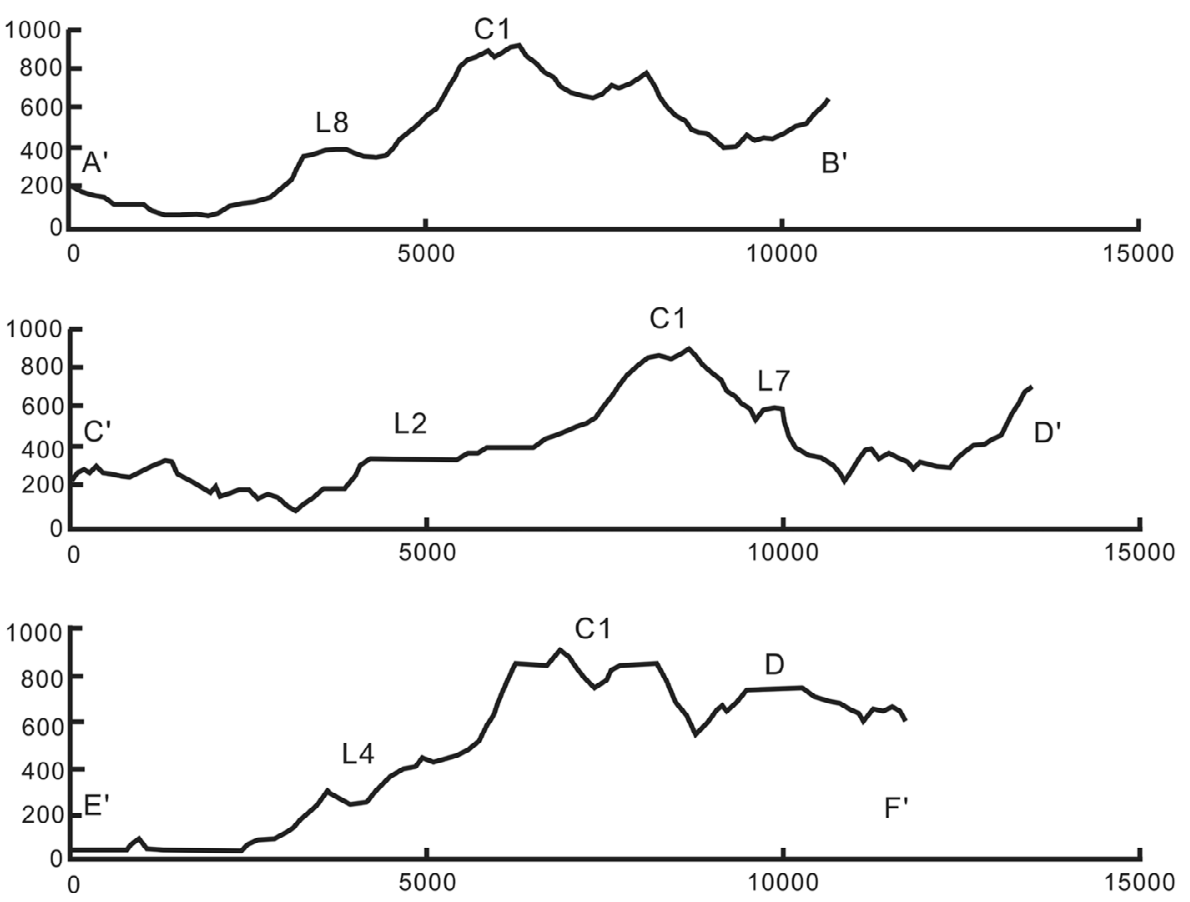

Fig. 5. Three cross sections cut through Mt. Huangtsui show the features of the volcanic landforms (marked in Fig. 2c) named section A' - B', C' D', and E' - F'. The labels are the same as in Fig. 2.

Table 1. The petrographic characteristics of the volcanic rocks from lava flows in the HVS.

\begin{tabular}{|c|c|c|c|c|c|}
\hline \multirow{2}{*}{$\begin{array}{l}\text { Lava flow } \\
\text { sequences }\end{array}$} & \multirow{2}{*}{ Distribution } & \multirow{2}{*}{ Groundmass } & \multicolumn{2}{|c|}{ Phenocrysts (modal vol.\%) } & \multirow{2}{*}{$\begin{array}{c}\text { Majority size of } \\
\text { phenocrysts }\end{array}$} \\
\hline & & & Hornblende & Pyroxene & \\
\hline $\mathrm{H} 13$ & Huantsuishan & porphyritic & 10 & $<5$ & $<0.3 \mathrm{~cm}$ \\
\hline H12 & Hsiufengping & porphyritic & $<5$ & 10 & $<0.3 \mathrm{~cm}$ \\
\hline H11 & Takungwei & porphyritic & $>10$ & $<5$ & $>0.3 \mathrm{~cm}$ \\
\hline $\mathrm{H} 10$ & Tianlai & porphyritic & 5 & $<10$ & $<0.3 \mathrm{~cm}$ \\
\hline H9 & Tachienhoushan & porphyritic & 5 & 10 & $<0.3 \mathrm{~cm}$ \\
\hline $\mathrm{H} 8$ & $\begin{array}{l}\text { Northern } \\
\text { Tachienhoushan }\end{array}$ & porphyritic & $>10$ & $<5$ & $<0.3 \mathrm{~cm}$ \\
\hline $\mathrm{H} 7$ & Taping & porphyritic & 1 & 10 & $<0.3 \mathrm{~cm}$ \\
\hline H6 & Payenshan & porphyritic & 10 & $<5$ & $>0.3 \mathrm{~cm}$ \\
\hline H5 & Tingshan & porphyritic & 10 & $<1$ & $<0.2 \mathrm{~cm}$ \\
\hline $\mathrm{H} 4$ & Tachienshan & porphyritic & 10 & $<5$ & $<0.3 \mathrm{~cm}$ \\
\hline $\mathrm{H} 3$ & Kengtou & porphyritic & $<5$ & $>10$ & $<0.3 \mathrm{~cm}$ \\
\hline $\mathrm{H} 2$ & Talunwei & porphyritic & 10 & $<5$ & $<0.3 \mathrm{~cm}$ \\
\hline H1 & Kongkuanlun & porphyritic & 10 & 5 & $<0.3 \mathrm{~cm}$ \\
\hline
\end{tabular}


Lahar, the epiclastic volcanic deposit occurs sporadically and is only distributed in incised valleys and distal apron of the HVS. They are usually poorly sorted and matrix-supported. It was formed by loose volcanic products mixed with the surface water or groundwater during or after eruptions and accumulated at the distal or fringe of this subvolcano group.

\subsection{Petrography}

Fifty-one specimens were collected from HVS to make thin sections and examine mineral assemblages and textures under optical microscopy. There are porphyritic with glomeroporphyritic textures in some samples and contain plagioclase, hypersthene, augite, hornblende, olivine and magnetite as phenocrysts. The groundmass is fine-grained to microcrystalline. Because of the partially hydrothermal alteration in those rocks, the reaction zoning and thermal decomposed grains can be observed in plagioclase, pyroxene and hornblende, especially for the hornblende grains. Some of the samples contain volcanic and sedimentary xenoliths with quartz xenocrysts. According to the mafic mineral species, such as hypersthenes, augite, hornblende and olivine, we can distinguish these andesites into seven rock types: the Ol-bearing Two-pyroxene Andesite [(Ol)T-And], the Ol-bearing augite Andesite [(Ol)Au-And], the Augite Andesite (Au-And), the Two-pyroxene Andesite (T-And), the Two-pyroxene hornblende Andesite (T-Hb-And), the Hornblende Two-pyroxene Andesite (Hb-T-And), the Hbbearing Two-pyroxene Andesite [(Hb)T-And].

\subsection{The Lava Flow Sequences of the HVS}

Chen and Wu (1971) noted volcanic rocks cropped out in the HVS into thirteen layers (S1 to S13) of interbedded lava flows and pyroclastic deposits in terms of the field occurrences and petrography. This study used $2 \mathrm{~m} \times 2 \mathrm{~m}$ DTM imagery to discern the margin of lava flows, then, perform a field survey to confirm the volcanic landforms, sequences and collected more than fifty specimens for further petrography studies.

Our study revised the previous lava flow sequences by two steps: (1) taking account of the characteristics of landforms, the principle of superposition and the law of crosscutting relationships from the DTM images to recognize different lava flows of the HVS; (2) based on the differences between petrography and the distance from the volcanic center to distinguish the sequences of lava flows. The results showed that at least thirteen lava flows of the HVS could be marked from the slope map, the shaded relief topography model and the difference of petrography, named the H1 to H13 (Fig. 6; Table 1).

$\mathrm{H} 1$ to $\mathrm{H} 5$ shows a more rugged surface than the others. It indicates that they may have suffered more erosion due to an earlier eruption. $\mathrm{H} 1$ to $\mathrm{H} 3$ spread around the northeastern to north of Mt. Huangtsui and $\mathrm{H} 4$ and $\mathrm{H} 5$ were situated at the southern part of the HVS. According to the DTM images, $\mathrm{H} 1$ to $\mathrm{H} 3$ are rougher than $\mathrm{H} 4$ and $\mathrm{H} 5$ implying that the former were formed earlier than the later (Fig. 6). Compared with the petrography and rugged surface, sequences of these five lava flows could be distinguished (Table 1)

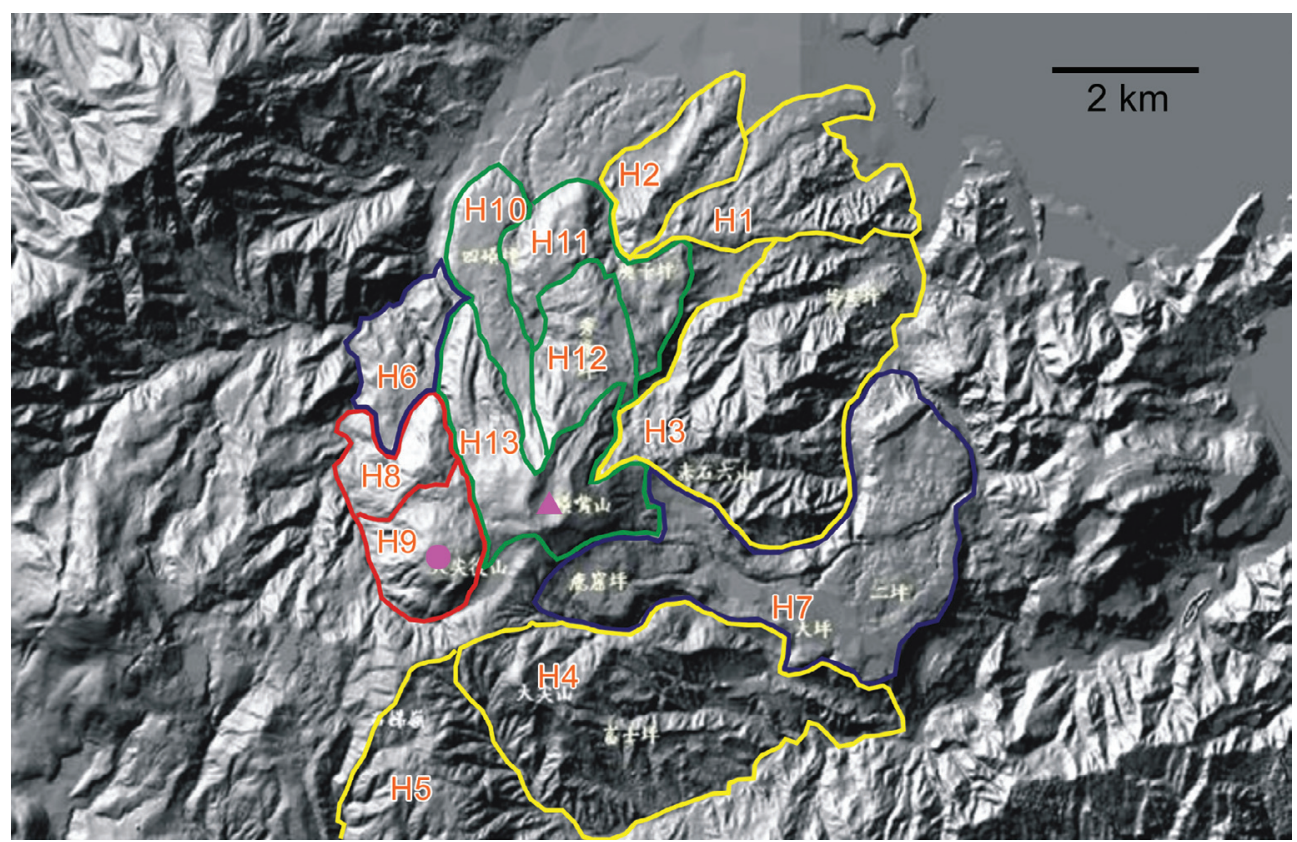

Fig. 6. Four stages of lava flows in the HVS area, marked yellow, blue, red and green, respectively. H1 to H13: thirteen lava flow sequences. Rock specimens were collected from the HVS and marked as the circles. The symbols are the same as in Fig. 2 and Table 1. 
and can be correlative to the results of Chen and $\mathrm{Wu}$ (1971), which $\mathrm{H} 1$ to $\mathrm{H} 3, \mathrm{H} 4$ and $\mathrm{H} 5$ were the same as $\mathrm{S} 2, \mathrm{~S} 3$ and $\mathrm{S} 4$, respectively (Table 2).

Flows of $\mathrm{H} 6$ and $\mathrm{H} 7$ were lavas with a smoother surface than above and spread more far away from the volcanic center. This might suggest that these two lava flows were older than those which were distributed nearby or around the centers of Huangtsui and Tachienhou volcanoes. Moreover, H6 was correlative to S5, and H7 to S6 and S7 (Chen and $\mathrm{Wu}$ 1971).

H8 to H13 was formed later because they overlaid the others and could be divided into two groups: H8, H9 and H10 to H13. The lava flows from the Huangtsui volcano changed the direction when it met the Tachienhou volcanic dome, therefore, $\mathrm{H} 10$ to $\mathrm{H} 13$ were the latest.

According to the principle of superposition, H8 was earlier than H9. Chen and Wu (1971) considered that lava flows poured from the Tachienhou volcano were older than those from the Huangtsui volcano, hence H8 and H9 were both correlative to S13. Finally, based on the relationships of crosscutting and superposition and petrography (Table 1), sequences of H10 to H13 could be distinguished and were also correlative to S8 and S12 of Chen and Wu (1971) (Table 2).

\section{DISCUSSION}

\subsection{The Resolutions of DTM}

Three different resolutions of DTM images were used in this study for comparison. The $40 \mathrm{~m} \times 40 \mathrm{~m}$ DTM image only shows a rough sketch of the mountains and the location of huge lava plateaus. Although the Huangtsui volcanic edifice and the lava plateaus, the Ta and Erh plateaus can be observed at this resolution (Fig. 2a), it was still too obscure to identify the small volcanic landforms and lava flows. Using the $10 \mathrm{~m} \times 10 \mathrm{~m}$ DTM image for the contour lines (Fig. 3) and the slope map (Fig. 4), the main volcanic bodies and lava plateaus can be recognized and discriminated clearly. The topography and shapes of volcanic landforms identified in this study were predominantly derived from this resolution; however, it still can't recognize the fine structures and contact relationships of lava flow. Upgrading the resolution to the $2 \mathrm{~m} \times 2 \mathrm{~m}$ (Fig. $2 \mathrm{c}$ ), the lava lobes, the orientation of lava flows and the pressure ridges can be distinguished easily. Meanwhile, the sequences of lava flow also can be determined by the principle of superposition and the law of crosscutting relationships.

Summarizing these three different resolutions of the DTM images, they can be selected to fit different purposes of application. The $40 \mathrm{~m} \times 40 \mathrm{~m}$ DTM image is used for preliminary recognition of the outline of the mountains. The $10 \mathrm{~m} \times 10 \mathrm{~m}$ DTM image is useful for determining the whole picture of volcanic edifice, major landforms, lava flow and plateau, and variations of slope. Promoting the resolution to the $2 \mathrm{~m} \times 2 \mathrm{~m}$ DTM image, it can be easily used to revise the detailed relationships of different flow and finer structures of lavas.

\subsection{The Volcanic Activity of the HVS}

The plateaus formed by lava flows in this study are shown in Table 3. The calculated volume of the lava plateaus showed large variations ranging from four to five times. For example, about $9.65 \times 10^{7} \mathrm{~m}^{3}$ and $5.25 \times 10^{8} \mathrm{~m}^{3}$, can be estimated for the volume of Hsiufeng and Ta-Erh lava plateaus, respectively, which the later is more than five times of the former. Based on the facts of diameters and altitude of volcano and estimated effusion volume, the Huangtsui volcano was too small to provide such a great quantity of lava flow to form the Ta-Erh plateau. A half-ring shape ridge around the Tachienhou volcanic dome forming a destructive caldera may be a candidate for an old volcano. After a large explosion releasing huge amounts of lava flow, this volcano collapsed due to partially emptied the magma chamber and formed a caldera (Fig. 2c).

\subsection{The Evolution of HVS's Activity}

Chen et al. $(2003,2007)$ recognized three stages of lava flow in the HVS using the $2 \mathrm{~m} \times 2 \mathrm{~m}$ LiDAR imagery combined with previously published results of petrography. However, our study identified at least seven rock types with complicated geomorphology of lava plateaus in the HVS (Table 2).

Based on the slope maps (Fig. 4), the landscape profiles (Fig. 5), the degree of weathering and erosion, and the detailed $2 \mathrm{~m} \times 2 \mathrm{~m}$ DTM image (Fig. 2c), these thirteen sequences of lava flows distinguished in this study can be reconstructed and categorized into four stages (Fig. 6). The lava flows of the first stage are distributed around the most distant apron of the volcano with the boundaries delimited by sharp changes of slope on the map (Fig. 6; Table 2). H1 to $\mathrm{H} 5$ was categorized in this stage. Lava plateaus of this stage were characterized by a more rugged surface than the others due to dense erosion. This stage might be the oldest volcanic activity in HVS.

Distributions of the lava flow in the second stage are predominantly located in the proximal area of the large volcano and formed the plateaus of Ta, Erh and Luku which were mainly composed of the lava flows of $\mathrm{H} 6$ and $\mathrm{H} 7$ (Fig. 6; Table 2). Previous studies suggested that most of the lavas forming the plateaus of them poured out from the Huangtsui volcano (Chen et al. 2003, 2007) which is a quite small volcano; however, lava volumes of those three lava plateaus are huge and they could not come from the magma effused from a small volcano like Mt. Huangtsui. Based on the topography and relative distributions of those lava plateaus, a relic ridge with half-ring shape can be recognized 
Table 2. The petrographic analyses of four stages of lava flow in the HVS.

\begin{tabular}{|c|c|c|c|c|}
\hline \multicolumn{3}{|c|}{ Stages of lava flows } & \multicolumn{2}{|c|}{ Lava flow sequences } \\
\hline \multirow{2}{*}{$\begin{array}{l}\text { this study } \\
1^{\text {st_Yellow }}\end{array}$} & \multicolumn{2}{|c|}{ (Chen et al. 2003, 2007) } & \multirow{2}{*}{$\begin{array}{c}\text { this study } \\
\mathrm{H} 1, \mathrm{H} 2, \mathrm{H} 3, \mathrm{H} 4, \mathrm{H} 5\end{array}$} & \multirow{2}{*}{$\begin{array}{c}\text { (Chen and Wu 1971) } \\
\text { S2, S3, S4 }\end{array}$} \\
\hline & $1^{\text {st_Orange }}{ }^{*}$ & $\mathrm{H} 1$ to $\mathrm{H} 5^{* *}$ & & \\
\hline $2^{\text {nd }}-$ Blue & $2^{\text {nd }}$-Green & H6 & H6, H7 & S5, S6, S7 \\
\hline $3^{\text {rd }}$-Red & \multirow{3}{*}{$3^{\text {rd }}$-Dark-green } & \multirow{3}{*}{$\mathrm{H} 7$ to $\mathrm{H} 13$} & $\mathrm{H} 8, \mathrm{H} 9$ & S13 \\
\hline & & & & \\
\hline $4^{\text {th }}-$ Green & & & H10, H11, H12, H13 & $\mathrm{S} 8, \mathrm{~S} 12$ \\
\hline
\end{tabular}

* The authors categorized the lava flows sequences from the TVG into seven stages, here showing four stages of HVS.

** A comparison of the lava flows stages from Chen et al. $(2003 ; 2007)$ with the thirteen sequences of lava flows from this work.

Table 3. The size scale of eight lava plateaus formed by lava flows.

\begin{tabular}{lccccc}
\hline Name & Lava flow sequence & Altitude $(\mathbf{m})$ & Area $\left(\mathbf{m}^{2}\right)$ & Thickness $(\mathbf{m})$ & Estimated volume $\left(\mathbf{m}^{3}\right)$ \\
\hline Szuhuang & H10 & 393 & $1.25 \mathrm{E}+06$ & 100 & $1.25 \mathrm{E}+08$ \\
Kengtze & $\mathrm{H} 11$ & 425 & $2.11 \mathrm{E}+06$ & 50 & $1.06 \mathrm{E}+08$ \\
Hsiufeng & $\mathrm{H} 12$ & 495 & $1.93 \mathrm{E}+06$ & 50 & $9.65 \mathrm{E}+07$ \\
Huanshan & $\mathrm{H} 3$ & 352 & $7.23 \mathrm{E}+06$ & 40 & $2.89 \mathrm{E}+08$ \\
Luku & $\mathrm{H} 7$ & 667 & $1.67 \mathrm{E}+06$ & 60 & $1.00 \mathrm{E}+08$ \\
Ta-Erh & $\mathrm{H} 7$ & 325 & $7.50 \mathrm{E}+06$ & 70 & $5.25 \mathrm{E}+08$ \\
Fushih & $\mathrm{H} 4$ & 442 & $6.72 \mathrm{E}+06$ & 40 & $2.69 \mathrm{E}+08$ \\
\hline
\end{tabular}

around the Tachienhou volcano. It was probably a collapsed caldera and was destroyed by later eruption or erosion. The huge amounts of lava flows, thus, forming the plateaus of Ta, Erh and Luku may have come from this old destroyed caldera.

The third stage was the Tachienhou volcanic dome. Based on the shaded relief topography model and the law of crosscutting relationships, the lava flow from the Huangtsui volcano changed its direction when it met the Tachienhou volcanic dome. It suggests that the Tachienhou volcanic dome was older than lava flows effused from the Huangtsui volcano. Lava flows of $\mathrm{H} 8$ and $\mathrm{H} 9$ belonged to this stage (Fig. 6; Table 2).

Lavas of $\mathrm{H} 10$ and $\mathrm{H} 13$ represent the latest stage of volcanism in the HVS. Flat and smooth surface of the plateaus with less erosion are the characteristics of these lava plateaus, such as the Szuhuang, Hsiufeng and Kengtze plateaus in this stage. Meanwhile, the lavas constituting the plateaus can be traced back to the summit of the Huangtsui volcano. They are predominantly distributed in the north of the Huangtsui volcano which it still retains the crater in the
TVG (Fig. 6). Therefore, those lines of evidence indicate that this stage of lava flows was the youngest products of volcanic activity in the HVS.

\section{CONCLUSION}

Combining the topography and slope model from the DTM images, the field occurrence, petrography and lithology, the geological map of the HVS is carefully redrawn in this study. The HVS consists of two major volcanic bodies: Mt. Tachienhou, an old caldera with a dome at the center and Mt. Huangtsui which is a composite volcano. They include eight lava plateaus which were made of thirteen lava flows and minor pyroclastics and epiclastics. Those volcanic rocks can be divided into seven types of andesites based on the assemblages and contents of mafic minerals. Images of $2 \mathrm{~m} \times 2 \mathrm{~m}$ DTM image are the most useful scale resolutions to identify the volcanic landforms. Four stages of the lava flows poured out from those two volcanoes can be identified. An old volcano erupted lava flows to form the former two stages. Then, it collapsed and formed a caldera 
with higher viscous lavas forming the Taichienhou volcanic dome inside it for the third stage. Finally, the latest stage of the lava flows was formed by the Huangtsui volcano eruptions with a crater at the summit.

Acknowledgements The authors appreciate the permission from the Central Geological Survey of MOEA to use LiDAR images in this study. This research was supported by the Central Geological Survey of MOEA under the grants CGS-MOE-5226902000-04-95-01.

\section{REFFERENCES}

Beutler, G., G. W. Hein, W. G. Melbourne, and G. Seeber (Eds.), 1995: GPS Trends in Precise Terrestrial, Airborne, and Spaceborne Applications. International Association of Geodesy Symposia, Vol. 115, Boulder, CO, USA, July 3-4, 1995, 275-338.

Burrough, P. A. and R. A. McDonell, 1998: Principles of Geographical Information Systems, Oxford University Press, New York, USA, 356 pp.

Cas, R. A. F. and J. V. Wright, 1987: Volcanic Successions: Modern and Ancient, Allen and Unwin, London, Boston, $528 \mathrm{pp}$.

Chen, C. H. and Y. J. Wu, 1971: Volcanic geology of the Tatun geothermal area, northern Taiwan. Proc. Geol. Soc. China, 14, 5-20.

Chen, C. H. and S. B. Lin, 2002: Eruptions younger than $20 \mathrm{Ka}$ of the Tatun Volcano Group as viewed from the sediments of the Sungshan Formation in Taipei Basin. West. Pac. Earth Sci., 2, 191-204.

Chen, C. H. and C. C. Lin, 2007: The recent eruption of the Tatun volcanic group: Inferred from juvenile volcanic ash in the Taipei basin. Abstract in the Annual Meeting of Geological Society Located in Taipei.

Chen, W. S., C. C. Yang, H. C. Yang, and J. K. Liu, 2003: Volcanic landform and sequences of the Tatun Volcanoes. Bull. Cent. Geol. Surv., 16, 99-123. (in Chinese)

Chen, W. S., C. C. Yang, H. C. Yang, J. K. Liu, Y. C. Chan, K. S. Shea, and, Y. C. Hsieh, 2007: Scanning laser mapping $(2 \mathrm{~m} \times 2 \mathrm{~m}$ DTM $)$ of the pleistocene Tatun volcanic landform. Bull. Cent. Geol. Surv., 20, 101128. (in Chinese)

Csatho, B., T. Schenk, W. Krabill, T. Wilson, W. Lyons, G. McKenzie, C. Hallam, S. Manizade, and T. Paulsen, 2005: Airborne laser scanning for high-resolution mapping of Antarctica. Eos, Trans., AGU, 86, doi: 10.1 029/2005EO250002. [Link]

Decker, R. and B. Decker, 1981: Volcanoes. W. H. Freeman, New York, 244 pp.

Ho, C. S., 1986: A synthesis of the geologic evolution of Taiwan. Tectonophysics, 125, 1-16, doi: 10.1016/004 0-1951(86)90004-1. [Link]

Juang, W. S. and J. C. Chen, 1989: Geochronology and geo- chemistry of volcanic rocks in northern Taiwan. Bull. Cent. Geol. Surv., 5, 31-66. (in Chinese)

Kraus, K., 1998: Fotogrammetria. In: Levrotto and Bella (Eds.), Torino, 445-496.

Lee, H. F., T. F. Yang, T. F. Lan, C. H. Chen, S. R. Song, and S. Tsao, 2008: Temporal variations of gas compositions of fumaroles in the Tatun Volcano Group, northern Taiwan. J. Volcanol. Geotherm. Res., 178, 624-635, doi: 10.1016/j.jvolgeores.2008.06.005. [Link]

Lee, S. F., 1996: Volcanic sequence study of the Tatun Volcano Group: The Chihsinshan Subgroup. Master Thesis, Institute of Geology, National Taiwan University, Taipei, Taiwan, ROC, 136 pp. (in Chinese)

Lin, C. H., K. I. Konstantinou, W. T. Liang, H. C. Pu, Y. M. Lin, S. H. You, and Y. P. Huang, 2005a: Preliminary analysis of volcanoseismic signals recorded at the Tatun Volcano Group, northern Taiwan. Geophys. Res. Lett., 32, L10313. doi: 10.1029/2005GL022861. [Link]

Lin, C. H., K. I. Konstantinou, H. C. Pu, C. C. Hsu, Y. M. Lin, S. H. You, and Y. P. Huang, 2005b: Preliminary results from seismic monitoring at Tatun volcanic area of northern Taiwan. Terr. Atmos. Ocean. Sci., 16, $563-$ 577.

Miller, C. L. and R. A. Leflamme, 1958: The digital terrain model-theory and application. Photogramm. Eng., 24, 433-442.

Song, S. R., S. Tsao, and H. J. Lo, 2000a: Characteristics of the Tatun volcanic eruptions, north Taiwan: Implications for a cauldron formation and volcanic evolution. J. Geol. Soc. China, 43, 361-378.

Song, S. R., T. F. Yang, Y. H. Yeh, S. Tsao, and H. J. Lo, 2000b: The Tatun volcano group is active or extinct? $J$. Geol. Soc. China, 43, 521-534.

Suppe, J., 1984: Kinematics of arc-continent collision, flipping of subduction, and back-arc spreading near Taiwan. Mem. Geol. Soc. China, 6, 21-34.

Teng, L. S., 1990: Geotectonic evolution of late Cenozoic arc-continent collision in Taiwan. Tectonophysics, 183, 57-76, doi: 10.1016/0040-1951(90)90188-E. [Link]

Tsai, Y. B., Z. S. Liaw, T. Q. Lee, M. T. Lin, and Z. H. Yeh, 1981: Seismological evidence of an active plate boundary in the Taiwan area. Mem. Geol. Soc. China, 4, 143-154.

Tsao, S, 1994: K-Ar age determination of volcanic rocks from the Tatun volcano group. Bull. Cent. Geol. Surv., 9, 137-154. (in Chinese)

Wang, K. L., S. L. Chung, C. H. Chen, R. Shinjo, T. F. Yang, and C. H. Chen, 1999: Post-collisional magmatism around northern Taiwan and its relation with opening of the Okinawa Trough. Tectonophysics, 308, 363-376, doi: 10.1016/S0040-1951(99)00111-0. [Link]

Wang, W. H. and C. H. Chen, 1990: The volcanology and fission track age dating of pyroclastic deposits in Tatun 
volcano group, northern Taiwan. Acta Geol. Taiwan., 28, 1-30.

Wilson, J. P. and J. C. Gallant, 2000: Terrain Analysis: Principles and Applications, John Wiley \& Sons Inc., New York, 479 pp.

Wu, F. T., 1978: Recent tectonics of Taiwan. J. Phys. Earth, 26, s265-s299.
Yang, T. F., 2000: The helium isotopic ratios of fumaroles from Tatun Volcano Group of Yangmingshan National Park, N. Taiwan. J. Natl. Park, 10, 73-94.

Yang, T. F., Y. Sano, and S. R. Song, 1999: ${ }^{3} \mathrm{He} /{ }^{4} \mathrm{He}$ ratios of fumaroles and bubbling gasses of hot springs in Tatun volcano group, north Taiwan. Nuovo Cimento, 22C, 281-286. 